\title{
The Western Reserve Historical Society and Its Library
}

This picture of a local historical society and its library was prepared by the director and secretary of the society at the suggestion of College and Research Libraries.

\section{The Challenge}

S everal years ago the Historical SoS ciety of Pennsylvania issued a statement of policy. The statement was a forthright discussion of the opportunities open to historical societies in general and of the policies which this Philadelphia organization had, after careful deliberation, decided to follow. It indicated also that the several historical societies in Philadelphia were trying to differentiate their fields. Incidentally, it was a challenge to other societies to clarify their aims. In line with this, and remembering that every such society is an agency that must serve its community, I am going to try to give the record of achievements and the purposes of Cleveland's historical society.

\section{A Little History}

The society was founded in 1867 . In the constitution the founders stated their objectives: "To discover, procure and preserve whatever relates to the history, biography, genealogy, antiquities and statistics connected with the City of Cleveland and the Western Reserve, and generally what relates to the history of Ohio and the Great West." They seemed to take as their field everything west of the Alleghenies. The name they adopted, however, appeared not to define, in a wholly satisfactory way, the scope of their work. For many years the secretary issued the call for meetings in the name of the "Western Reserve and Northern Ohio Historical Society." On the title page of the society's publications, "The Western Reserve" in small capitals occupied one line and in the next line, the central point of the page was "And Northern Ohio Historical Society," in heavily leaded capitals, as though it were the real thing to be held in mind. As a matter of fact, "Western Reserve" is a geographical term that began to lose meaning after the organization of the state of Ohio and ceased to have a significant place with the division of the territory that had been Connecticut's Western Reserve into counties and townships like other portions of Western states. As long as northeastern Ohio was occupied by a population predominantly from Connecticut stock the phrase had some purport to that group. But now it means just what "Cleveland" would mean in the name of an organization. Northeastern Ohio, the Western Reserve, is every part within sixty miles of Cleveland, and describes a metropolitan area that the society would like to serve as other such agencies serve their community. As symbolic of this, the society now has branches at Mentor (the Garfield Home) and at Unionville (the Harper Home).

The chief organizers were Judge Charles C. Baldwin and Colonel Charles Whittle- 
sey. Both were men of broad interests and long vision. From the first they planned a library, a museum, a forum for discussion of historical subjects by the members, public lectures, and publications, and every part of this program was observed in practice throughout their times. Whittlesey, the first president, was for many years employed by the United States in the survey of the Upper Peninsula of Michigan and particularly in the exploration of the copper and iron resources of the region. He was a prolific writer on the resources of the Great Lakes region. Baldwin, the second president and for many years secretary, expressed his collecting interests in purchasing early maps of Ohio, the Great Lakes, North America, and, in fact, of the entire field of the explorers of the Americas. His was a splendid collection of cartography. The homes of both founders indeed were small museums. The collections of both were given to the society which they founded-archeological specimens, maps, manuscripts, pamphlets, and books of their own authorship. Seldom have two such prolific writers combined to found a historical society.

As organized in 1867 , the society was a department of the Cleveland Library Association (later known as Case Library) and remained so until it took out a state charter as an independent body in 1892 . The parent association started the society off, as a good parent should, with some of the old home place-a gift of the books the association held on local and Ohio history. That gift made it a going concern as a history library from the outset. Many of the early members added private collections to fill museum cases. Still it was relatively a small institution housed in one room until 1892. From the first days two purposes prevailed - to build a library and a museum, the one to provide both the raw materials of history and the finished prod- ucts, the other to preserve illustrative objects which would vitalize history.

In the early years the society's members met in private homes for business, discussions, and lectures. Such activities constituted a very prominent feature. The lectures were published as tracts of the society. After the society built at University Circle, it had for a few years a hall for such purposes. However, by I9I4 the crowded conditions of the building compelled the trustees to use this for book stacks. The loss of the hall and the competition of other agencies around University Circle offering lecture series, caused the abandonment of both the forum and the lectures. Publications, several a year, were continued until the depression of the I930's cut the society's resources. A publication fund established in $\mathbf{I} 942$ has made possible in a limited way the revival of one of the most marked features of the early days, the promotion of productive scholarship. Some of the more popular of the early publications are still in print and in demand as well.

\section{The Library}

I. Maps. The library contains four main divisions, devoted respectively to maps, manuscripts, newspapers, and printed works, including books and pamphlets. The core of the map and atlas collection was assembled by Baldwin. There are a great number of manuscript maps of Western Reserve townships and the original surveys of the Connecticut Land Company, representing nearly every township. In addition there are numerous early maps of Ohio towns. The society supplemented these with atlases and maps that came in purchases and gifts. In 1943 President Norton gave one of the rare early Cleveland maps. There are nearly five hundred photostatic copies of maps in the Bibliothèque Nationale. There are about four hundred atlases. Atlases and maps have all been fully cataloged. 
2. Manuscripts. Presidents Whittlesey and Baldwin not only gave the society the manuscripts in their own files of correspondence and of private papers but aggressively sought those of their friends and associates. In the early years the Cuyahoga County commissioners financed for the society the purchase of the records of the Connecticut Land Company-maps, deeds, correspondence, and the field notes of the company's surveyors. The records of the secretary, Ephraim Root, were also obtained by the society. Taken together it was a prize collection for a society which took as its smallest allotted field the Western Reserve and constituted indeed a priceless manuscript collection. The papers of the agents of the land company resident in the reserve came in later as a matter of course. There were those of Turhand Kirtland, Abram Tappan, Simon Perkins, Peter and Reuben Hitchcock, and others, the correspondence, journals, diaries, account books, surveys, and maps complementing the records of the Connecticut Land Company proper. These, with others which the families of the pioneers have given, cover business and social life on the reserve from 1795 to the Civil War.

The list of manuscripts would be very large. Wallace H. Cathcart, who as director of the society had a major part in building up the collections, once estimated the number at one million items. Elisha Whittlesey, of Canfield, Ohio, uncle of Charles Whittlesey and a Whig politician and congressman for many years, left some ninety thousand letters, mostly correspondence with his party associates. As late as 1916 the director could report to the trustees that the society had received the John May papers, a body of manuscripts pertaining to the affairs of the Connecticut Land Company and the Ohio Land Company, ranging in dates from 1787 to $181 \mathrm{I}$. The Governor Allen Trimble papers contain a large body of early surveys of the Virginia Military District in Ohio, embracing land warrants and maps. The correspondence and papers of Ephraim Brown, founder of Bloomfield, Ohio, the recollections and other papers of Leonard Case, and the diary of his son, William, illustrate items that are too numerous for enumeration. They are exceptionally valuable for the place and the time they represent.

The William P. Palmer collection includes a vast number of letters, diaries, journals, and other papers on Southern life on plantations and on slavery and the Civil War. There are, for example, five volumes of the journals of the Chamouni and the $\mathrm{El}$ Destino plantations in Louisiana, 1842-55. The Bragg papers of the Civil War, military correspondence largely, are only an illustration of the Civil War materials in manuscript form. More striking is the Shaker manuscript collection consisting of letters, diaries, journals, and records of every form, and representing nearly all of the nineteen separate Shaker communities. It is unique in size and also in the form in which the Shaker ministry preserved its records for the posterity of "the world" from which it wished to escape. The manuscripts came to the society both bound and legible.

The manuscript division contains a large body of local business records, those of the Cleveland iron companies being among the most prominent. Among these are the records of the first iron works in the citythe Cuyahoga Steam Furnace Company. In recent years the letters and other papers of Senator Theodore Burton, long-time representative from Cleveland in Congress, and those of Myron T. Herrick, close associate of McKinley and governor and ambassador to France, have come to the society. The McKinley letters and the ambassador's correspondence in the years I9I3-I4 and 1921-29 are a rich mine for American historians. 
3. Newspapers. The newspaper division of the library contains more than twentyfive thousand bound volumes and thousands more of unbound and partial or fragmentary files. Photostatic copies of many newspapers published in the American colonies have been purchased. The division was greatly extended by the Palmer collection, with about twenty-two thousand issues published in the Confederate States of America. There are unbroken files of all of the leading Cleveland newspapers and of many other Ohio cities. There is an almost complete file of one of the oldest Ohio newspapers, the Scioto Gazette, from 1801-57; an extensive run of the Liberty Hall and Cincinnati Gazette, 1812-37; and one of the Ohio State Journal from 1826 to date. The Trump of Fame, 1812-16, and the Western Reserve Chronicle, 1816-1920, give the society an almost complete newspaper record of Warren, Ohio, and Trumbull County. The file for Elyria, Ohio, is practically complete. But the collection is in no sense limited to Ohio towns. For the National Intelligencer, Washington, D.C., there is an almost complete set of the triweekly for $1800-6 \mathrm{I}$ and of the daily from 1813-69. The file of New England newspapers is extensive. The Columbian Centinel, Boston, is almost complete for 1788 1820. There are runs of the New York Herald for 1802-14, 1860-96, of the New York Times for 1860-96 and 1912-27, and of the Tribune for 1845-96. By exchange of duplicates the society acquired the London Chronicle for an important period of American history, 1757-1800.

4. Periodicals. The society in its periodical collection, closely related to the newspaper collection, emphasizes the preservation of the national, regional, and state historical magazines. While it has extensive files of many periodicals, like Harper's Weekly, it does not intend to develop a periodical division in competition with those at Western
Reserve University and the Cleveland Public Library. In this respect there is a fairly definite understanding with those institutions.

5. Books. Books and pamphlets constitute the major division of the library. The society does not have an accurate count of the number of books and pamphlets on its shelves. Mr. Cathcart put it at four hundred thousand. There are, however, probably twenty-five thousand duplicates. Purchases had a larger share in building the library proper than any other part of the society's collections. This came about because Mr. Cathcart pushed vigorously his policy of making the library serve historical scholarship. But he also visited older and greater libraries and was remarkably successful in persuading librarians to give duplicates to his society. He went to Washington and to many state capitals for files of public documents that were still available. The sections of the library on colonial and state public records were built up in this manner and are now quite complete. Also, the library was a depository for the government serial set until 1900, and its file for the first thirteen Congresses is one of the most extensive in the United States.

It is of passing interest that Mr. Cathcart began his collecting career as a student at Denison University, assembling everything he could secure by gift or purchase bearing on the history of the Baptist Church in Ohio. His interests broadened as he proceeded and came to include other denominational publications. How could he remain a Baptist without knowing why he couldn't be something else! This was typical of his whole career as a bookman. He had, before he finished, built up an extensive library of American church records, including notable collections of Mormon and Shaker literature. In fact, the Cathcart Shaker collection is the finest of its kind anywhere. It is a mass of material, as yet almost unex- 
plored by scholars, on the social conditions of a peculiar people, but throwing light on the social conditions of pioneers in many parts of the United States.

6. Special Collections. William P. Palmer, president of the American Steel and Wire Company, was president of the society from 1913-28. His private collection of books, pamphlets, newspapers, and manuscripts on slavery, the Civil War, and Lincoln was given to the society. Two recent gifts of Lincolniana, one by Mrs. George R. Lamb, whose husband had made a collection, and another by the daughters of Stephen W. Tener, have filled many gaps in the Palmer library. The section constitutes one of the society's richest stores of sources and secondary works. Among the accessions which would be found in any important national listing are Judge Henry C. White's collection of Arctic exploration; Charles G. King's books on the history of costume, international in scope and of every age; and the D. Z. Norton library of Napoleonic works, outstanding in the United States and, because the volumes are beautifully bound, a joy to behold. (For an appraisal, see John H. Stewart's Guide to Materials in Cleveland, 1715-1815, p. 27I.)

\section{Special Support}

In the golden era of universities and privately-supported institutions which followed World War I, Mr. Cathcart was very successful in securing special support for his program of book buying. Certain members of the society agreed to underwrite considerable annual purchases, each on a subject in which he had a personal interest. For example, Samuel Mather financed for several years the purchase of such English parish registers as could be found. F. F. Prentiss authorized the securing of books on Ohio history; William McLauchlan, those on Maine; L. A. Mur- fey, those on Pennsylvania; Jeptha $\mathrm{H}$. Wade, those on New Jersey; Henry S. Sherman, those on Mormonism; Ralph King, those on costume; Mrs. Louis J. Smith, those on genealogy; Cyrus S. Eaton, those on the American loyalists; H. A. Fuller, those on California ; and the Van Sweringen brothers, those on Virginia and Maryland and later on genealogy as well. In that way many gaps that had developed from the voluntary giving of books were filled. It was the most fruitful of the director's policies toward the systematic assembling of a great library. It lasted until the great depression of the thirties put an end to book buying on a large scale. Mr. Cathcart, himself, built up for the society by exchange and purchase, an outstanding, almost perfect, collection of early Ohio laws, besides that of the early congressional documents already mentioned. Other special collections which have come to the society are Palmer's on the Lewis and Clark expedition, Otto Miller's on the War of I812, Franklin S. Terry's on World War I, Cyrus S. Eaton's on the French and Indian Wars, with many rare books and pamphlets, and Charles C. Baldwin's collection of early imprints.

\section{Genealogy}

The section on genealogy contains some fifteen thousand volumes on individual American families, besides general material, society publications, and vital records. It is one of the most active parts of the library, requiring the full-time services of a genealogist. Limitation of space here precludes a description of the accumulation of deeds, legal papers, land grants, and broadsides which have drifted in over the years. The Brody amateur newspapers and the early American prints, especially of Ohio and Civil War music (sheet and broadsides), are outstanding.

7. The Catalog. The library has been 
fully listed, being in almost all cases fully classified and cataloged; and although much remains to be done before the society can boast a perfect catalog of its collections, many research workers comment upon the utility of the catalog and are amazed at its completeness. The staff is small, but every effort is made to give reference service by telephone, by mail, and in the library itself. Interlibrary loans are made, with the usual exceptions observed by rare-book libraries; and photostat and film service is supplied by a commercial firm. The library's holdings are listed in the Union List of Serials, the Union List of Newspapers, Cleveland Regional Union Catalogue, and the common bibliographical tools. In addition to the main book catalog, the library maintains a separate manuscript catalog, a newspaper checklist, a periodical checklist, a Shaker catalog and membership list, a costume catalog, a broadsides catalog, an almanac checklist, a portrait index, a map and atlas catalog, a coat of arms index, and many others, all of which are useful bibliographies in themselves.

\section{New Quarters}

The mushroomlike growth of the library in the first quarter of the twentieth century absorbed the space intended for the museum, just as it had that allotted to a lecture hall. The balance was not restored until in recent years (I939-4I) when the president of the society, Laurence $H$. Norton, conceived the plan and arranged for the purchase of two large residences on East Boulevard, facing Wade Park, and the transfer of the library into one of them and the museum into the other. The new site has ample space for several additional buildings, enough to meet any needs now foreseen. One of the buildings, the McKinney house, originally built by Mrs. John Hay for her Cleveland home, and for many years the residence of the Price McKinney family, provides the so- ciety with twenty-six exhibition rooms, an assembly hall, work rooms, and storage space, and now constitutes the main part of the museum. The building is an impressive structure, surrounded by beautiful patios and gardens. The other residence, adjacent to the Hay-McKinney house, and connected with it by passageways, was built by Harry Payne Bingham in 1918 and occupied later by the Leonard C. Hanna, Sr., family for many years. Like the museum building, the library building is Florentine in style. The two harmonize with each other and have a setting of terraces and formal gardens, which are much used in the summer season by visitors and for social occasions. Twenty-two rooms and a basement are now occupied by the library collections. Since moving to the new site the museum has grown as the library had in earlier years, until it may be said to have taken its old place as one of the society's major services to the public.

\section{Permanent Exhibitions}

Certain rooms in the museum are set aside for permanent exhibitions. Two are given to the D. Z. Norton Napoleonic collection, one to the George W. Bierce Washingtoniana, another to Mr. Bierce's early American lighting exhibits, several to period costumes, one to Shaker relics, and others to objects representative of early American homes, shop tools, and farm utensils. In the wing given over to an exhibition of the handicrafts of Indians, Eskimos, Mexicans, and Peruvians, is the exceptionally fine collection of pre-Inca pottery presented to the society by William H. Hunt. The museum is more than an institution with static exhibitions, that is, with all exhibits on permanent showing. Many of its rooms are changed every few days or weeks. A large portion of the collection is kept in storage rooms to be placed on exhibition in rotation, to use for special events, to illustrate special 
subjects, or to go out on loan. The society's large accumulations of stamps, coins, paper money, and medals are just now being integrated, classified, and otherwise prepared for use in rotating exhibits. The same is true of the extensive collections of prints, photographs, and posters. Some of these are notable. Examples are the Ambrose Swasey gifts of freshly minted coins, many of them never in circulation; the S. Houghton Cox stamp collection; the J. D. Cox, Sr., Washington medals and Washington prints; Dr. H. K. Cushing's Franklin prints; and the William P. Palmer Civil War portraits and battle scenes. Again as in the cases of the major manuscript collections, this list gives a vague idea of the hundreds of thousands of objects which make up a museum.

\section{An Educational Institution}

A museum is an educational institution. It undertakes to visualize human events by the use of relics, facsimiles, dioramas, and pictures. In effect it constitutes an extension of the local educational system. In the case of this society, thousands of school children come to the museum for illustrative lessons in history. Special exhibitions are assembled to meet the needs of such classes. These may be of a pioneer home, of the costumes and furnishings of a particular period, or of the working tools or machines of some time or event which the classes in a school are at the moment studying. The opportunities for the use of such instruments of popular education, be it for schools, clubs, adults, or juveniles, are boundless. The museum is in fact the dynamic part of a modern historical society. It can adapt its policies to the changing needs of a community. There was a time when, in the present instance, the emphasis of the society's search for museum material was on the Indian relics and archeology in general. Then the time came when it is obvious the officers were thinking of the pioneer living conditions of the white man's frontier. The objects that came to the society were of rural or small village life. The Cleveland of modern times is a great lake port, iron center, and industrial community. It is natural that the emphasis should now be shifting to the collection of materials which have to do with shipping on the Great Lakes and with manufacturing.

\section{In the Postwar Period}

The Western Reserve Historical Society faces postwar conditions knowing that it will have a vital part to play. It will offer the community a library rich in the raw materials of historical research and many rare printed works. It has a staff eager and able to assist visitors in their research, and to give any and all the latest conclusions of others' research in the history of the United States. Through its museum it will be prepared to visualize the life of the past in innumerable aspects. The entire community will be served as only a few metropolitan areas can be. Careful consideration is being given to the relations of the society's activities with those of the other cultural agencies in Cleveland. The purchasing officers of the Cleveland Public Library, of Western Reserve University, and of the society, are in constant communication in order to avoid needless duplication and to clarify their respective fields. The officers of all Cleveland museums have an intermuseum icommittee or council to keep clear their respective museum activities. By cooperation of all these forces there should develop cultural forces of a high order. 